\title{
THE INFLUENCE OF PROBLEM BASED LEARNING ON THE ABILITY TO COMPLETE STORY QUESTIONS IN GRADE V MADRASAH IBTIDAIYAH MIMA AL HUDA
}

\author{
M. Sholahuddin Amrulloh ${ }^{1}$ \\ ${ }^{1}$ Universitas Islam Negeri Kiai Haji Achmad Siddiq, Jember, Indonesia
}

\section{Article Info}

\section{Article history:}

Received: 03-12-2020

Revised: 20-12-2021

Published: 31-01-2022

\section{Keywords:}

Problem Based Learning

Story Questions

Madrasah Ibtidaiyah

ABSTRACT

This study aims to determine the effect of the problem-based learning model on the ability to solve math story problems in the fifth grade of Madrasah Ibtidaiyah Mima Al Huda in the 2020/2021 school year. This study uses research, the type of Quasi Experimental Design type one group Pretest-Posttest Design. The subjects of this study were all fifth-grade students of Madrasah Ibtidaiyah Mima Al Huda. The data collection technique used was a written math test in the form of a description of 5 items that had met the validity. The hypothesis test in this study used a paired sample t-test. Before testing the hypothesis, the data obtained were tested for normality and homogeneity of the data. Based on the calculation of hypothesis testing with $t$ test, it is obtained that $t$-value is $-12,162$ while ttable is 2,060 at a significance level of $5 \%$ with df 25 . So that tcount $-12,162>2,060$ it can be stated that Ha is accepted and H0 is rejected, which means there are differences in the ability to solve math story problems between before and after receiving the problem-based learning model treatment. Based on the results of this study, it can be concluded that the problem-based learning model has an effect on the ability to solve math story problems for the fifth-grade elementary school students at Madrasah Ibtidaiyah Mima Al Huda.
\end{abstract}

This is an open access article under the CC BY-SA license.

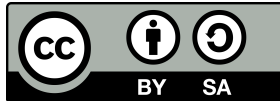

\section{Corresponding Author:}

Izzaturrahmah,

Elemetary Education Study Program, Universitas Mataram

Jl. Majapahit No. 62, Mataram, Indonesia

Email: izaarahma97@gmail.com

\section{INTRODUCTION}

The objectives of Mathematics Subjects in Elementary School are contained in the Content Standards (SI) in Permendiknas No. 22 of 2006. The SI stated five objectives of learning mathematics, one of the five objectives is so that students are able to solve mathematical problems which include the ability to understand problems, design mathematical model, complete the model and interpret the solution obtained. Therefore, every elementary school teacher must practice their skills in helping students learn to solve mathematical problems (Efriani, Hapizah, \& Putri, 2019).

Most students have difficulty in solving problems because students cannot interpret the concepts contained in story problems, cannot formulate story questions into mathematical models, and cannot choose and use appropriate solving strategies. This is caused by learning mathematics which places more emphasis on 
numeracy skills than mastery of concepts. Sunaringtyas et al. (Sunaringtyas, Asikin, \& Junaedi, 2017), said that "teachers in learning are still focused on achieving student abilities in counting and using mathematical formulas, while students' problem-solving abilities are still considered as additional extra abilities". Many teachers are satisfied with learning calculations and think that problem solving learning takes a lot of time, so it often interferes with the learning program. In the end, problem solving learning is neglected (Ainiyah, Istiningsih, \& Mataram, 2021). The impact is that the problem-solving ability of students in solving problems in elementary schools is still very low. Several studies reported that the difficulty of elementary school students in learning mathematics in general was in understanding problems and solving story problems (Tzohar-Rozen \& Kramarski, 2014). Students are not able to apply mathematical concepts in the form of solving problems in everyday life.

The success of learning mathematics is influenced by various factors, one of which is the student's attitude towards mathematics. Attitudes towards mathematics include three components, namely components of cognition, affective cognition, and conation (Lisesi, 2017). The cognitive component is composed of the knowledge and information a person has about the object of his or her attitude, the effect component is evaluative which relates to feelings of pleasure and displeasure, and the co-native component is a person's readiness to behave in relation to the object of his or her attitude or components related to the tendency to act towards object. Students' mathematical attitudes cannot be ignored in mathematics learning because they have an influence on learning (Hotimah, Ermiana, \& Rosyidah, 2021; Santia, Purwanto, Sutawidjadja, Sudirman, \& Subanji, 2019).

Therefore, a learning model is needed that can improve problem solving skills and can develop students' mathematical attitudes in solving story problems. One of the learning models that are thought to be able to improve students' problem-solving abilities and mathematical attitudes is Problem Based Learning (PBL). PBL presents authentic problems that can be formulated and solved together in groups. According to Tello (2010), PBL is a learning that has the essence of presenting various authentic and meaningful problematic situations to students.

PBL can focus students on the learning process and enable students to reinvent concepts, reflect, abstraction, formalization, problem solving, communication and application. PBL can also support a fun and student-centred mathematics learning process. Students are given the opportunity to find problems around them that can be used as problems in the learning process (Oktaviani, Hartono, \& Marwoto, 2017). Students are given the opportunity to think about solving the problem through discussion with their classmates. Thus, it will train students to think critically, creatively, and be able to solve mathematical problems which can foster students' positive attitude towards mathematics (Nyoman, Astuti, Setiawan, \& Mataram, 2021). Based on the problems described above, the researchers used research using a learning model. According to the researchers, this model fits the current problem. Therefore, the researcher conducted a research entitled "The Influence of Problem Based Learning Model on the ability to solve story problems for fifth grade students of Madrasah Ibtidaiyah Mima Al Huda".

\section{RESEARCH METHOD}

The type of research used is experimental research. Sugiyono (2016), suggests that experimental research is a research method used to find the effect of certain treatments on others under controlled conditions. According to Van Hoecke (2016), there are several forms of experimental research designs, namely: PreExperimental Design, True Experimental Design, Factorial Design, Quasi Experimental Design. The research design used was Pre-Experimental Design type one group pretest-posttet Design. This research was conducted on one experimental class group that was not chosen randomly. The experimental class was previously given a pretest to determine the initial state of students' ability to solve math story problems before being given treatment (treatment). So the results of the treatment can be known more accurately, because it can compare with the situation before being treated. The instruments used in this study were observation sheets, tests and documentation. The test was tested to determine the validity of an instrument so that it could be used to measure the subject under study. These instruments have been previously validated.

\section{RESULT AND DISCUSSION}

At the initial stage, the researcher gave an initial test (pre-test) with the aim of seeing the initial abilities of students from each individual. The next stage was the researcher gave treatment in the form of applying the Problem Based Learning learning model in two meetings, using the help of image media and The media is in 
the form of boxes in the form of nets of blocks and cubes. In the final stage after being given treatment, the researcher gave a final test (posttest) with the aim of seeing the difference in learning outcomes between before being given treatment and after being given treatment. The following is data on student learning outcomes (pretest-posttest) for fifth grade students of Madrasah Ibtidaiyah Mima Al Huda.

Table 1. Pretest and Post-test result data

\begin{tabular}{clcc}
\hline No & Aspects to Pay Attention to & pre-test & post-test \\
\hline 1 & lowest value & 40 & 60 \\
2 & the highest score & 80 & 95 \\
3 & average value & 65.58 & 81.15 \\
4 & number of students taking the test & 26 & 26 \\
5 & Number of students whose score is $>70$ & 11 & 24 \\
6 & Number of students whose score is 70 & 15 & 2 \\
7 & Complete presentation & $42.3 \%$ & $92.3 \%$ \\
\hline
\end{tabular}

From the data on the average value of the pre-test and post-test of the ability to solve math story problems for grade V Madrasah Ibtidaiyah Mima Al Huda above, it can be seen that the average score of students on the initial test (pre-test) is 65.58 with a high score of 80 and the lowest score was 40 . Furthermore, the average score produced in the post-test was 81.15 with the highest score of 95 and the lowest score of 60 .
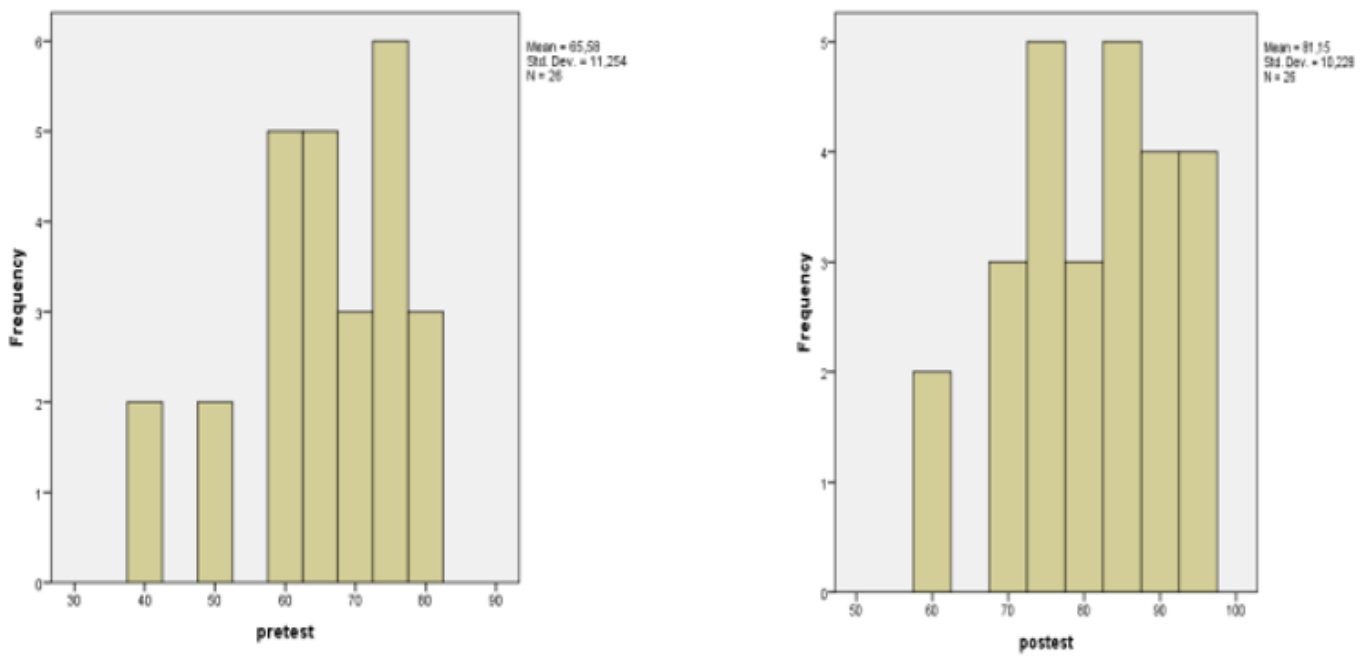

Figure 1. Data Diagram of Student Pre-test and Post-test Results

Based on the diagram above, it can be seen that the results of the development of skills in solving math story problems for fifth grade students after being given treatment (post-test) were better than the results before being given treatment (pre-test). This can be seen from the highest post-test score of 95, the lowest of 60 with an average score of 81.15 . While the value before being given treatment the highest score was 80 , the lowest was 40 with an average value of 65.58 .

After the data on the students' skills in solving mathematical story problems (pre-test and post-test) were obtained, the data normality test was then carried out. The normality test of the data in this study used the Kolmogorov-Smirnov normality test with the help of the SPSS Version 16 application with a significance level of $5 \%$ or 0.05 , on the pre-test and post-test data of students in the experimental class. So the data is said to be normally distributed if the significance value is greater than 0.05 . The results of the normality test of the data obtained using the Kolmogorov-Smirnov test are presented in the following table:

Table 2. Normality Test Results of Pre-test and Post-test Data

\begin{tabular}{lcccc}
\hline \multirow{2}{*}{ Data } & \multirow{2}{*}{ Class } & \multicolumn{3}{c}{ Kolmogorov-Smirnov } \\
\cline { 3 - 5 } & & Statistics & df & Sig. \\
\hline Pretest & Experiment & 0.156 & 26 & 0.102 \\
Posttest & Experiment & 0.147 & 26 & 0.157 \\
\hline
\end{tabular}


Based on Table 2, it can be seen that all data are normally distributed because all data in the sig column is greater than 0.05 . The pre-test data is 0.102 , normally distributed because the significance value is greater than 0.05 , which is 0.1020 .05 . The post-test significance value is 0.157 , it is said that the post-test data is normally distributed because the significance value is greater than 0.05 , namely 0.1570 .05 .

The homogeneity test of the data was used to determine whether the data of the two samples had homogeneous variants or not, in order to fulfill the prerequisite test for parametric statistics. The homogeneity test was carried out using the One-Way ANOVA test with the help of the SPSS Version 16 statistical analysis program on pre-test and post-test data. from the ability to solve math story problems of students in class V. The data are said to be homogeneously varied if the significance value of the One-Way ANOVA test is $>0.05$. On the other hand, the data is said to have non-homogeneous variance if the significance value of the One-Way ANOVA test is $<0.05$. Based on the results of the homogeneity test carried out using the One-Way ANOVA test, it is presented in Table 3 as follows:

Table 3. Homogeneity Test Results with One Way ANOVA

\begin{tabular}{rccc}
\hline Levene Statistic & df1 & df2 & Sig. \\
\hline 0.019 & 1 & 50 & 0.892 \\
\hline
\end{tabular}

Based on the table above, to determine whether the data variance is homogeneous or not, the only thing to note is Sig. obtained that is equal to 0.892 If the significance value of the variance of the post-test data and post-test data is the same or homogeneous because the significance value is more than 0.05 , that is 0.8920 .05 . Before testing the hypothesis, the parametric statistical test conditions for data must be normal and homogeneous. Analysis of the normality test has been carried out using the Kolmogorov Smirnov calculation where the value of all Sig 0.05 at a significance level of 5\% means the research data is normally distributed. While the homogeneity test used the calculation of the one way ANOVA test with Sig. 0.8920 .05 , it can be concluded that the data is homogeneous. Because the parametric statistical test requirements have been met, we can test the hypothesis.

Hypothesis testing is used to determine the effect of problem based learning learning models on the ability to solve math story problems. Hypothesis testing uses t-test and independent sample t-test test with the help of SPSS version 16. Hypothesis test decision making can be seen by comparing the t-count value with t-table or by comparing Sig. with $=0.05$.

Based on the results of the hypothesis test of students' ability to solve math story problems above, the results of t-value $=-12,162$ are greater than t-table $=2,060$ which shows Ha is accepted and $\mathrm{H} 0$ is rejected, which means that there are differences in the ability to solve math story problems between before and after receiving treatment with the problem based learning model. on the ability to solve math story problems for fifth grade elementary school students at Madrasah Ibtidaiyah Mima Al Huda.

This study aims to determine the effectiveness of using the Problem Based Learning (PBL) model on the ability to solve math story problems for class V Madrasah Ibtidaiyah Mima Al Huda for the 2020/2021 school year. The results of the study show that the problem-based learning model has an effect on the ability to solve math story problems for fifth grade students of Madrasah Ibtidaiyah Mima Al Huda for the 2020/2021 school year. The existence of this influence is proven from the results of research and data analysis that there is a difference in the average value of the ability to solve math story problems that are positive and significant before and after being given treatment in the form of applying problem based learning models in the learning process (Al Ani \& Al Attar, 2017; Lee \& Hong, 2021). This research begins with giving pretest to students with the aim of seeing students' initial abilities. The average student pretest results were 65.58 with the highest score of 80 and the lowest being 40 .

Furthermore, the researchers gave treatment by applying the Problem Based Learning (PBL) learning model in mathematics subjects for 2 meetings. The first meeting was on October 19, 2020 and the second meeting was on October 20, 2020. The research provided Posttest to students to find out student learning outcomes after being given treatment. The average posttest of students is 81.15 with the highest score reaching 95 and the lowest being 60. When compared with the average value of the student's pretest, it has increased. After testing the prerequisites, then testing the hypothesis using the independent sample t-test with the help of SPSS version 16. The calculation of the hypothesis testing with the t-test is obtained by $\mathrm{t}$-value $-12,162$ while $\mathrm{t}$-table is 2,060 at a significance level of $5 \%$ with df 25 . So t-value $-12,162>2.060$, it can be stated that Ha is accepted and $\mathrm{H} 0$ is rejected, which means that there is a difference in the ability to solve math story problems 
between before and after receiving the problem-based learning model treatment. Based on the results of this study, it can be concluded that the problem based learning model has an effect on the ability to solve math story problems for the fifth grade elementary school students at Madrasah Ibtidaiyah Mima Al Huda.

\section{CONCLUSION}

Based on the results of the research and discussion presented, it can be concluded that there are differences in the ability to solve math story problems between before and after receiving treatment with the problem based learning model in fifth grade students of Madrasah Ibtidaiyah Mima Al Huda in the 2020/2021 lesson." This can be seen from the hypothesis testing that has been carried out using the Independent Sample T-test with the help of SPSS 16. It can be seen that the significance value of learning outcomes ttest $=0.000$ indicates that the ttest value $0.05(0.0000 .05)$, which if interpreted into the existing hypothesis testing provisions are that $\mathrm{Ha}$ is accepted and $\mathrm{HO}$ is rejected. Thus, the purpose of the research to determine the effectiveness of using the Problem Based Learning (PBL) model on the ability to solve math story problems for class V Madrasah Ibtidaiyah Mima Al Huda for the 2020/2021 school year, has been achieved.

Based on the results of the research and discussion that have been put forward, some suggestions that can be given are as follows: (1) For students, it can be used as an option in the teaching and learning process, so that they prefer the content of learning Mathematics; (2) For teachers, it can be used as a model choice in teaching Mathematics so that it can affect the quality of teaching and learning activities, especially in the content of learning Mathematics; (3) For researchers, they can continue their research using problem based learning learning models with other subjects and to measure learning outcomes in affective and psychomotor aspects; (4) For educational institutions and related schools, they can provide input for educators in their schools, through the application of problem based learning learning models as one of the innovations in the learning process, especially in learning mathematics. In an effort to improve the quality of educators in their schools.

\section{REFERENCES}

Ainiyah, N., Istiningsih, S., \& Mataram, U. (2021). Pengaruh Penggunaan Metode Everyone Is A Teacher Here the Effect Of Using Everyone Is A Teacher Here Method On. Renjana Pendidikan Dasar, 1(1).

Al Ani, M. A., \& Al Attar, A. T. (2017). The Role of Private School Principals in Total Quality Mangagement and its Relation with Educational Leadership Style. Journal of Educational and Psychological Studies [JEPS], 11(3), 687. doi:10.24200/jeps.vol11iss3pp687-706

Efriani, A., Hapizah, \& Putri, R. I. I. (2019). Sailing Context in Pisa-Like Mathematics Problems. Journal on Mathematics Education, 10(2), 265-276.

Hotimah, H., Ermiana, I., \& Rosyidah, A. N. K. (2021). Pengembangan Multimedia Interaktif Berbasis Macromedia Flash Untuk Meningkatkan Kemampuan Komunikasi Matematis. Progres Pendidikan, 2(1), 7-12. doi:10.29303/prospek.v2i1.57

Lee, G.-G., \& Hong, H.-G. (2021). John Amos Comenius as the prophet of modern ideas in science education: in the light of Pansophia. History of Education, 50(1), 1-26. doi:10.1080/0046760X.2020.1836265

Lisesi, Ç. K. M. T. A. (2017). Examining The Problem Solving Skills and The Strategies Used by High School Students in Solving Non-routine Problems. E-International Journal of Educational Research, 8(2), 91114. doi:10.19160/ijer.321075

Nyoman, N., Astuti, S., Setiawan, H., \& Mataram, U. (2021). Pengaruh Model Concept Sentence Berbantuan Flash Card Correlation of Teacher Personality Competence With Discipline of Student Learning in Grade 5 At Sd Negeri Gugus I Lopok Academic Year 2020 / 2021. Renjana Pendidikan Dasar, 1(1), 35-43.

Oktaviani, P., Hartono, H., \& Marwoto, P. (2017). Pengembangan Multimedia Interaktif Bervisi SETS sebagai Alat Bantu Model Problem Based Learning (PBL) dalam Pembelajaran IPA di SMP untuk Meningkatkan Kemampuan Berpikir Kritis dan Keterampilan Sosial Peserta Didik. PSEJ (Pancasakti Science Education Journal), 2(2), 125-137. doi:10.24905/psej.v2i2.746

Santia, I., Purwanto, P., Sutawidjadja, A., Sudirman, S., \& Subanji, S. (2019). Exploring Mathematical Representations in Solving Ill-Structured Problems: The Case Of Quadratic Function. Journal on Mathematics Education, 10(3), 365-378. doi:10.22342/jme.10.3.7600.365-378

Sugiyono. (2016). Metode penelitian kuantitatif kualitatif dan $R \& D$. Bandung: Alfa Beta. 
Sunaringtyas, A. D., Asikin, M., \& Junaedi, I. (2017). The Student's Analysis of Creative Thinking Process in Solving Open Problems Viewed from Wallas Model on Problem Based Learning Model. Unnes Journal of Mathematics Education, 6(3), 287-293. doi:10.15294/ujme.v6i3.16084

Tello, E. A.-c. (2010). Making Mathematics Word Problems Reliable Measures of Student Mathematics Abilities. Journal of Mathematics Education, 3(1), 15-26.

Tzohar-Rozen, M., \& Kramarski, B. (2014). Metacognition, Motivation and Emotions: Contribution of SelfRegulated Learning to Solving Mathematical Problems. Global Education Review, 1(4), 76-95.

Van Hoecke, M. (2016). Methodology of Comparative Legal Research. doi:10.5553/rem/.000010 